NASA/CR-2001-210612

\title{
Microelectromechanical Systems (MEMS) Actuators for Antenna Reconfigurability
}

Rainee N. Simons

Dynacs Engineering Company, Inc., Brook Park, Ohio

Donghoon Chun and Linda P.B. Katehi

University of Michigan, Ann Arbor, Michigan 
Since its founding, NASA has been dedicated to the advancement of aeronautics and space science. The NASA Scientific and Technical Information (STI) Program Office plays a key part in helping NASA maintain this important role.

The NASA STI Program Office is operated by Langley Research Center, the Lead Center for NASA's scientific and technical information. The NASA STI Program Office provides access to the NASA STI Database, the largest collection of aeronautical and space science STI in the world. The Program Office is also NASA's institutional mechanism for disseminating the results of its research and development activities. These results are published by NASA in the NASA STI Report Series, which includes the following report types:

- TECHNICAL PUBLICATION. Reports of completed research or a major significant phase of research that present the results of NASA programs and include extensive data or theoretical analysis. Includes compilations of significant scientific and technical data and information deemed to be of continuing reference value. NASA's counterpart of peerreviewed formal professional papers but has less stringent limitations on manuscript length and extent of graphic presentations.

- TECHNICAL MEMORANDUM. Scientific and technical findings that are preliminary or of specialized interest, e.g., quick release reports, working papers, and bibliographies that contain minimal annotation. Does not contain extensive analysis.

- CONTRACTOR REPORT. Scientific and technical findings by NASA-sponsored contractors and grantees.
- CONFERENCE PUBLICATION. Collected papers from scientific and technical conferences, symposia, seminars, or other meetings sponsored or cosponsored by NASA.

- SPECIAL PUBLICATION. Scientific, technical, or historical information from NASA programs, projects, and missions, often concerned with subjects having substantial public interest.

- TECHNICAL TRANSLATION. Englishlanguage translations of foreign scientific and technical material pertinent to NASA's mission.

Specialized services that complement the STI Program Office's diverse offerings include creating custom thesauri, building customized data bases, organizing and publishing research results ... even providing videos.

For more information about the NASA STI Program Office, see the following:

- Access the NASA STI Program Home Page at http://www.sti.nasa.gov

- E-mail your question via the Internet to help@sti.nasa.gov

- Fax your question to the NASA Access Help Desk at 301-621-0134

- Telephone the NASA Access Help Desk at 301-621-0390

- Write to:

NASA Access Help Desk

NASA Center for AeroSpace Information 7121 Standard Drive

Hanover, MD 21076 
NASA/CR-2001-210612

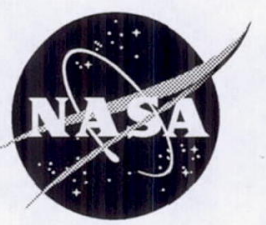

\section{Microelectromechanical Systems (MEMS) Actuators for Antenna Reconfigurability}

Rainee N. Simons

Dynacs Engineering Company, Inc., Brook Park, Ohio

Donghoon Chun and Linda P.B. Katehi

University of Michigan, Ann Arbor, Michigan

Prepared for the

2001 International Microwave Symposium

cosponsored by the Institute of Electrical and Electronics Engineers and the Microwave Theory and Techniques Society

Phoenix, Arizona, May 20-25, 2001

Prepared under Contract NAS3-98008

National Aeronautics and

Space Administration

Glenn Research Center 


\section{Acknowledgments}

The authors are grateful to Gary Lesney for the design and fabrication of a DC power supply for the MEMS actuators, the Office of Naval Research for their support under contract N0001498-1-0628, and the NASA CETDP under code SM.

This report contains preliminary

findings, subject to revision as analysis proceeds.

Available from

NASA Center for A.erospace Information 7121 Standard Drive

Hanover, MD 21076

Price Code: A02
National Technical Information Service 5285 Port Royal Road Springfield, VA 22100 Price Code: A02 


\title{
Microelectromechanical Systems (MEMS) Actuators for Antenna Reconfigurability
}

\author{
Rainee N. Simons \\ Dynacs Engineering Company, Inc. \\ National Aeronautics and Space Administration \\ Glenn Research Center \\ Cleveland, Ohio 44135 \\ Donghoon Chun and Linda P.B. Katehi \\ University of Michigan \\ Radiation Laboratory, EECS Department \\ Ann Arbor, Michigan 48109-2122
}

\begin{abstract}
A novel microelectromechanical systems (MEMS) actuator for patch antenna reconfiguration is presented for the first time. A key feature is the capability of multi-band operation without greatly increasing the antenna element dimensions. Experimental results demonstrate that the center frequency can be reconfigured from few hundred $\mathrm{MHz}$ to few $\mathrm{GHz}$ away from the nominal operating frequency.
\end{abstract}

\section{INTRODUCTION}

In recent years microelectromechanical systems (MEMS) based switching and actuating devices have emerged as a viable alternative to solid state control devices in microwave systems. The MEMS devices offer the following advantages [1] first, significant reduction in insertion loss, which results in higher figure-of-merit. Second, they consume insignificant amount of power during operation, which results in higher efficiency. Third, they exhibit higher linearity and as a result lower signal distortion when compared to semiconductor devices. In addition, it has been also demonstrated that MEMS based switches and actuators can enhance the performance of antennas. For example, a patch antenna on a suspended micromachined fused quartz substrate that can rotate can perform spatial scanning of the beam [2]. A Vee-antenna with moveable arms constructed from polysilicon material can steer as well as shape the beam [3]. Furthermore, a field programmable metal array consisting of several thousand microswitches placed along the perimeter of a patch antenna can provide frequency reconfigurability [4].

In this paper, we present two new digitally reconfigurable patch antennas via use of MEMS actuators. The key features are first, the capability of multi-band operation without greatly increasing the antenna element dimensions, thus allowing for use in planar phased arrays. Second, each actuator requires only a single bias line for control, which implies greatly simplified construction and operation.

\section{MEMS ACTUATOR DESIGN}

Patch antennas with two independent MEMS actuators and with two MEMS actuators in series are illustrated in
Figs. 1 and 2, respectively. Each actuator consists of a moveable metal overpass suspended over a metal stub. The overpass is supported at either ends by metalized vias which are electrically connected to the patch antenna. The metal overpass is free to move up and down and is actuated by an electrostatic force of attraction set up by a voltage applied between the overpass and the metal stub as illustrated in Fig. 3. A dielectric film deposited over the metal stub prevents stiction when the surfaces come in contact. The metal strip of length $\mathrm{L}$ and width $\mathrm{W}$ attached to the metal stub behaves as a parallel plate capacitor. The patch antenna operates at its nominal frequency as determined by the dimension $b$ when the actuator is in the OFF state. The actuator is in the ON state when the overpass is pulled down by the electrostatic force due to the bias, and the capacitance of the metal strip appears in shunt with the input impedance of the patch antenna. This capacitance tunes the patch to a lower operating frequency. During the synthesis process, the inductance and capacitance of the actuators and their locations in the patch should be taken into account in order to ensure a constant input impedance.

\section{MEMS ACTUATOR FABRICATION}

The first step is the metal deposition and patterning using the lift-off process for, the patch, the microstrip feed line, the capacitive metal strips, and the probe pads. The metalization is titanium/gold and the thickness is about $0.8 \mu \mathrm{m}$. The substrate is a high resistivity silicon wafer $\left(\rho>3000 \Omega \mathrm{cm}, \varepsilon_{\mathrm{r}}=11.7, \mathrm{~h}=400 \mu \mathrm{m}\right)$. Second, an insulating layer to support the overpass is built-up to the required thickness by multiple spin-coats of spin-on-glass (SOG) $\left(\mathrm{h}_{1}=2.0 \mu \mathrm{m}, \varepsilon_{\mathrm{r} 1}=3.1\right)$. Third, using photoresist and dry etching techniques, the SOG over the metal stub is partially removed leaving behind a dielectric film which is about $3000 \AA$ thick to prevent stiction. Fourth, via holes $(\mathrm{d}=35 \mu \mathrm{m})$ for the vertical interconnects are patterned using photoresist and dry etching techniques. Fifth, the metal overpass $\left(\mathrm{L}_{\mathrm{p}}=380 \mu \mathrm{m}, \mathrm{W}_{\mathrm{p}}=80 \mu \mathrm{m}\right)$ is fabricated using titanium/gold by a lift-off and electroplating 
process. This step metalizes the via holes as well and ensure electrical continuity between the patch and overpass. The thickness of the overpass metal is about $2.0 \mu \mathrm{m}$. In the last step, the sacrificial photoresist layer below the overpass is removed by super critical $\mathrm{CO}_{2}$ dry release process. Rectangular holes $10 \times 10 \mu \mathrm{m}$ in size are provided in the overpass to facilitate the removal of the sacrificial layer. The photomicrographs in Figs. 4 (a) and (b) show the MEMS actuator as viewed from the top and the span of the overpass, respectively.

\section{EXPERIMENTAL RESULTS AND DISCUSSIONS}

Patch antennas with the integrated MEMS actuators are experimentally characterized by measuring the return loss, $\mathrm{S}_{11}$, as a function of the frequency with and without the actuation voltage. The return loss is measured using a ground-signal-ground RF probe calibrated to the tips using an impedance standard substrate. The actuation voltage is $55 \mathrm{~V}$.

\section{A. Patch With Two Independent Actuators}

Experimental Results. - The measured return loss for the two states of the actuators are shown in Figs. 5(a) through (c). When both the actuators are in the OFF state, the patch resonates at its nominal operating frequency of about $25.0 \mathrm{GHz}$ as shown in Fig. 5(a). The $-10.0 \mathrm{~dB}$ return loss bandwidth of the patch is about 3.3 percent. When actuator \#1 is in ON state and actuator \#2 is in the OFF state, the resonant frequency $\left(f_{r}\right)$ shifts to about $24.8 \mathrm{GHz}$ as shown in Fig. 5(b). Similarly, when actuator $\# 1$ is in the OFF state and actuator \#2 is in the ON state, the $f_{r}$ shifts to $24.8 \mathrm{GHz}$. This result is expected since the two actuators are identical in construction. The step change of $200 \mathrm{MHz}$ in the $\mathrm{f}_{\mathrm{r}}$ for both cases is about 0.8 percent of the patch nominal operating frequency. Finally, when both actuators are in the $O N$ state, the $f_{r}$ is 24.6 GHz as shown in Fig. 5(a). The shift is twice as much as the case, when a single actuator is turned ON. Furthermore at resonance, the magnitudes of the return loss are almost equal for the two states, implying minimum loss of sensitivity. Thus for this configuration, the patch antenna can be dynamically reconfigured to operate at different bands separated by a few hundred $\mathrm{MHz}$, by digitally addressing either actuators or both actuators. This is a desirable feature in mobile wireless systems to enhance capacity as well as combat multipath fading.

Numerically Simulated Results (Method of Moments). - The computed $\mathrm{f}_{\mathrm{r}}$ as a function of the length $\mathrm{L}$ and the width $\mathrm{W}$ as parameters are presented in Fig. 6.
This figure shows that for small L $(380 \mu \mathrm{m})$ and $\mathrm{W}$ $(50 \mu \mathrm{m})$, the $\mathrm{f}_{\mathrm{r}}$ is $25.93 \mathrm{GHz}$, which is equal to the $\mathrm{f}_{\mathrm{r}}$ of an identical patch without actuators and metal strips. Further, for a fixed $\mathrm{W}$ as $\mathrm{L}$ increases, the $\mathrm{f}_{\mathrm{r}}$ decreases and can be precisely controlled to a few tens of $\mathrm{MHz}$.

\section{B. Patch With Two Series Actuators}

The measured return loss of the patch antenna with the MEMS actuator in the ON and OFF states are shown in Fig. 7. It is observed that when the actuator is in the OFF state the patch resonates at about $25.4 \mathrm{GHz}$. When the actuator is in the ON state, the $f_{r}$ shifts to $21.5 \mathrm{GHz}$. This is a first experiment and impedance matching at $21.5 \mathrm{GHz}$ was not optimized. The numerically simulated $f_{r}$ is about 21.6 GHz. Thus for this configuration, the patch antenna can be dynamically reconfigured to operate at two different bands separated by a few $\mathrm{GHz}$, such as, for transmit and receive functions in satellite communications.

\section{CONCLUSIONS}

Two novel frequency reconfigurable patch antenna elements with integrated MEMS actuators are presented for the first time. These patches can be dynamically reconfigured to operate at frequencies separated by about 0.8 to 15 percent of the nominal operating frequency. Furthermore, the actuators are simple to fabricate and also compatible with array antennas. At the present time, these actuators are used in an array environment to reconfigure not only the resonant frequency but also the phase of the radiated signal from the individual elements.

\section{REFERENCES}

[1] S.P. Pacheco, L.P.B. Katehi, and C.T.-C. Nguyen, "Design of Low Actuation Voltage RF MEMS Switches," 2000 IEEE MTT-S Inter. Microwave Symp. Dig., vol. 1, pp. 165-168, Boston, MA, June 11-16, 2000.

[2] D. Chauvel, N. Haese, P.-A. Rolland, D. Collard, and H. Fujita, "A Micro-Machined Microwave Antenna Integrated with its Electrostatic Spatial Scanning," Proc. IEEE Tenth Annual Inter. Workshop on Micro Electro Mechanical Systems (MEMS 97), pp. 84-89, Nagoya, Japan, Jan. 26-30, 1997.

[3] J.-C. Chiao, Y. Fu, I.M. Chio, M. DeLisio and L.-Y. Lin, "MEMS Reconfigurable Vee Antenna," 1999 IEEE MTT-S Inter. Microwave Symp. Dig., vol. 4, pp. 1515-1518, Anaheim, CA, June 13-19, 1999.

[4] S.M. Duffy, "MEMS Microswitch Arrays for Reconfigurable Antennas," Notes of the Workshop "RF MEMS for Antenna Applications," 2000 IEEE Ant. and Prop. Inter. Symp., Salt Lake City, UT, July 16, 2000. 

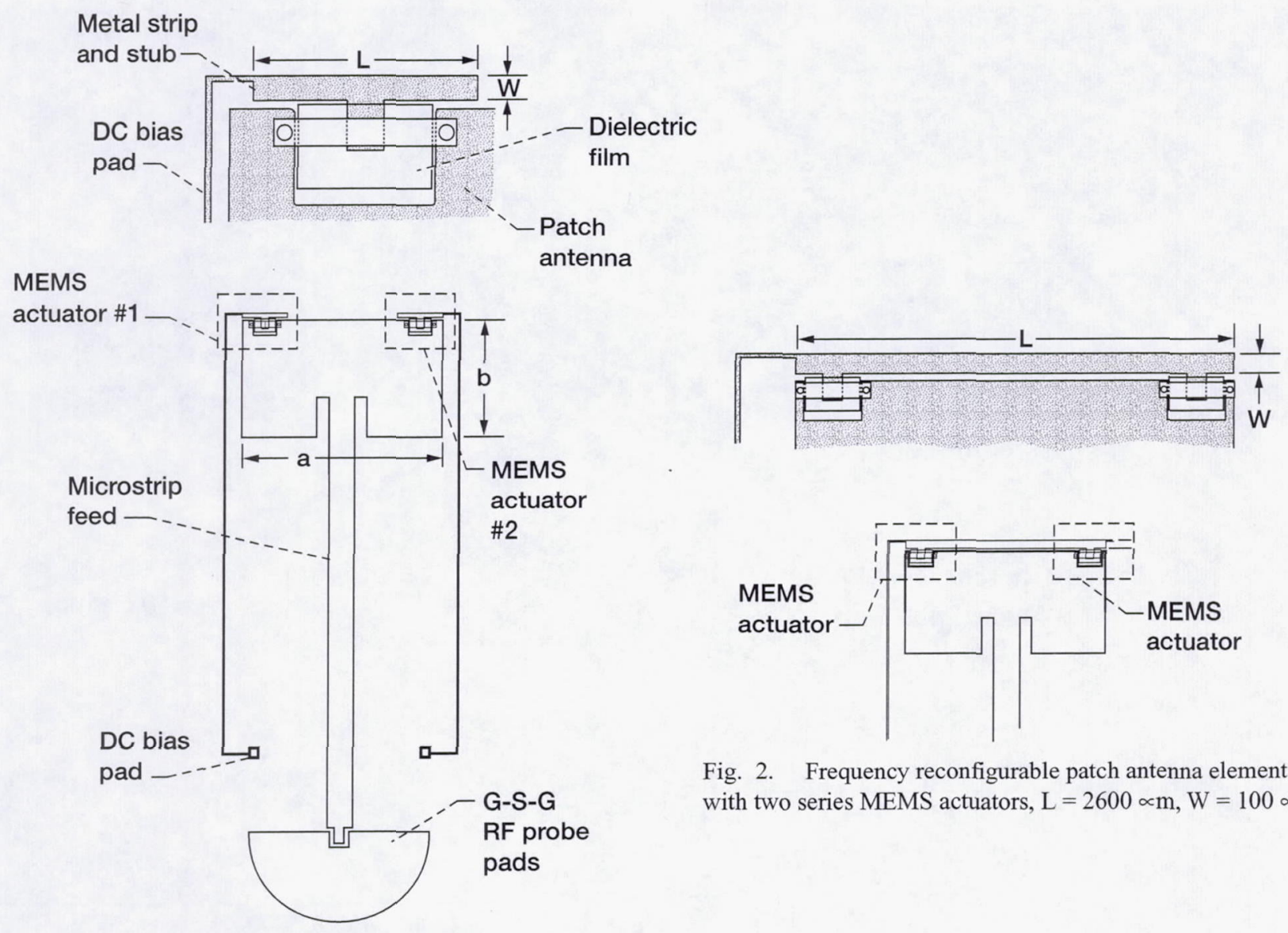

Fig. 2. Frequency reconfigurable patch antenna element with two series MEMS actuators, $\mathrm{L}=2600 \propto \mathrm{m}, \mathrm{W}=100 \propto \mathrm{m}$

Fig. 1. Frequency reconfigurable patch antenna element with two independent MEMS actuators, $\mathrm{L}=580 \propto \mathrm{m}, \mathrm{W}=50 \propto \mathrm{m}, \mathrm{a}=2600 \propto \mathrm{m}$, $\mathrm{b}=1500 \propto \mathrm{m}$.

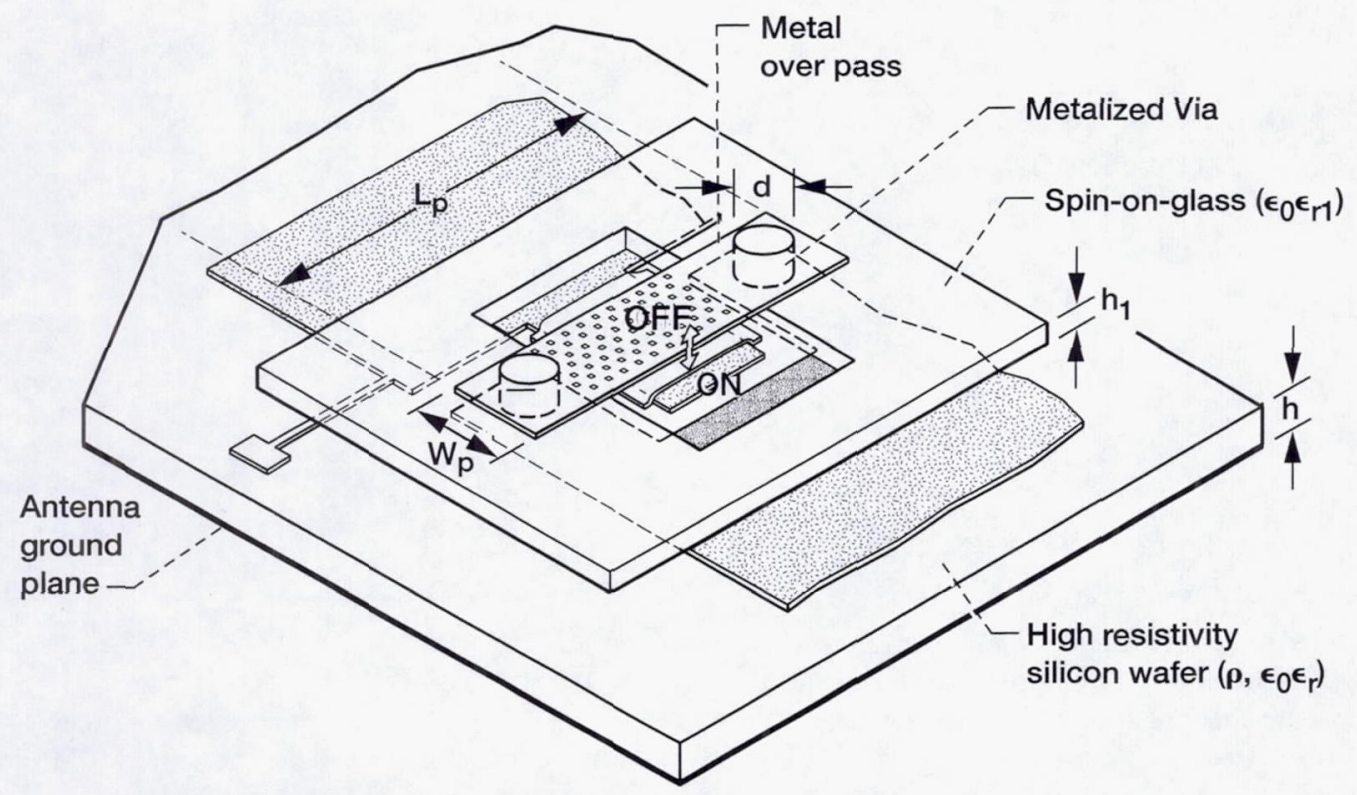

Fig. 3. Schematic of a MEMS actuator integrated with a patch antenna element. 

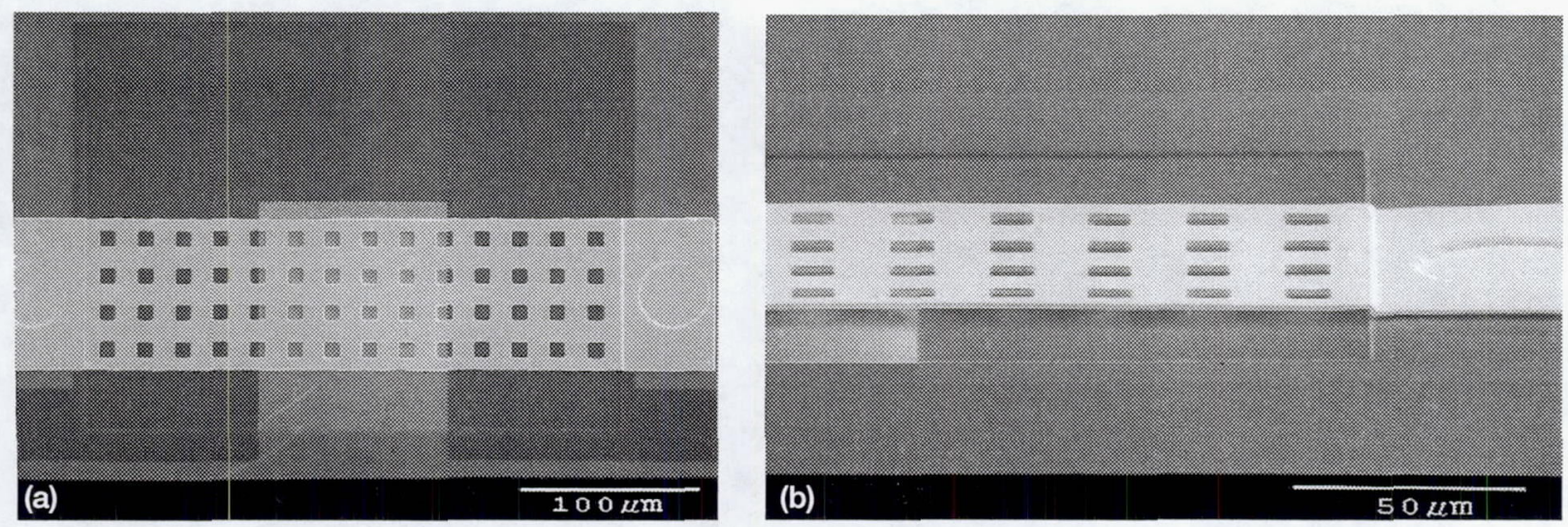

Fig. 4. Photomicrograph of a MEMS actuator. (a) Top view. (b) Side view.
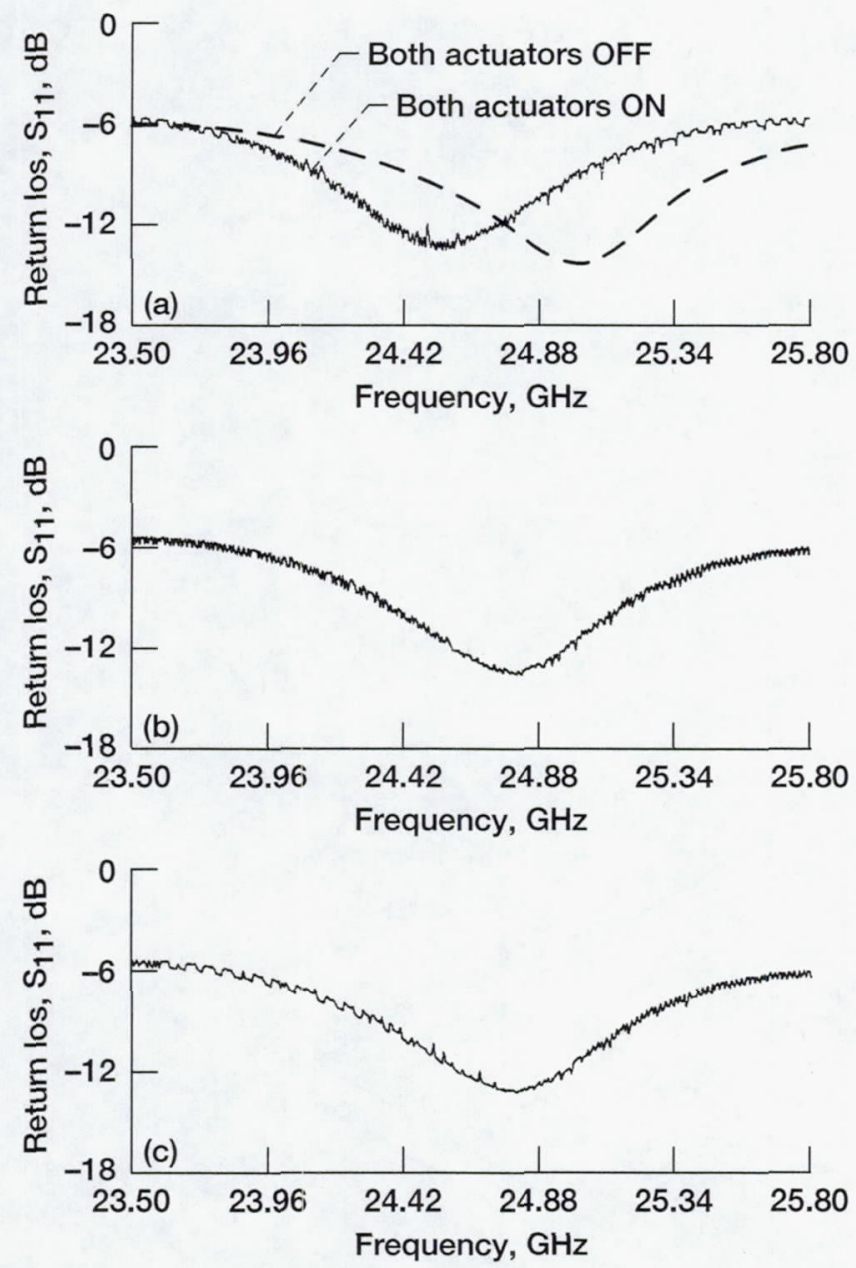

Fig. 5. Measured return loss demonstrating frequency reconfigurability when the MEMS actuators are biased independently. (a) Both actuators are either in the OFF state or ON state. (b) Actuator \#1 is ON and actuator \#2 is OFF. (c) Actuator \#1 is $\mathrm{OFF}$ and actuator $\# 2$ is $\mathrm{ON}$.

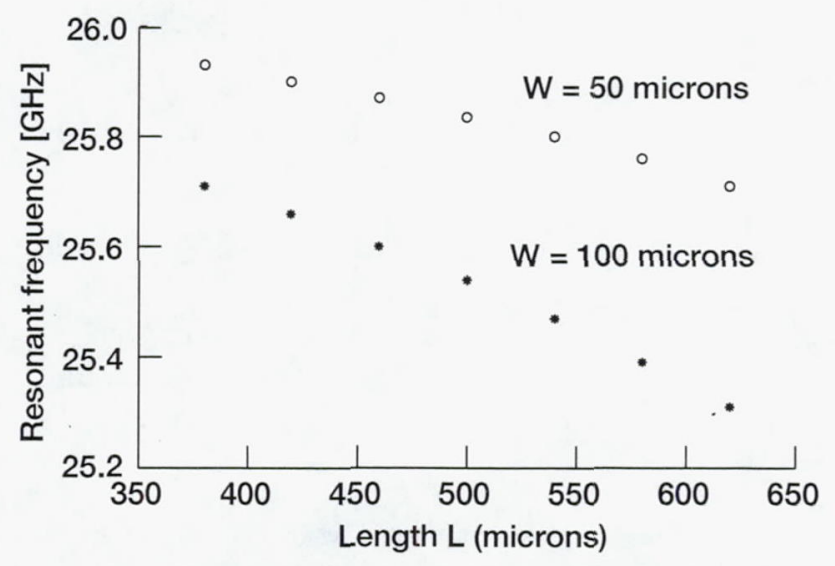

Fig. 6. Computed resonant frequency as a function of the actuator length and width for patch antenna element with two independent MEMS actuators.

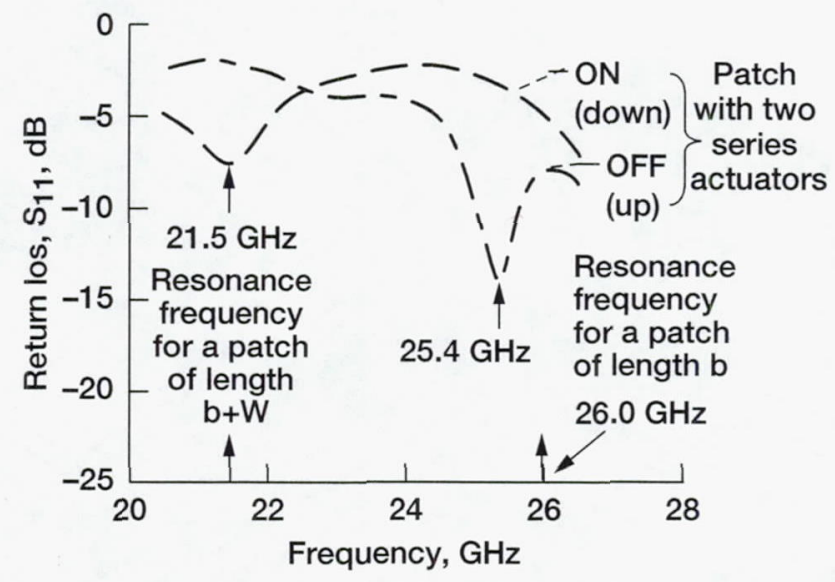

Fig. 7. Measured return loss demonstrating frequency reconfigurability when the two series MEMS actuators are either in the OFF state or ON state. 
Public reporting burden for this collection of information is estimated to average 1 hour per response, including the time for reviewing instructions, searching existing data sources, gathering and maintaining the data needed, and completing and reviewing the collection of information. Send comments regarding this burden estimate or any other aspect of this collection of information, including suggestions for reducing this burden, to Washington Headquarters Services, Directorate for Information Operations and Reports, 1215 Jefferson Davis Highway, Suite 1204, Arlington, VA 22202-4302, and to the Office of Management and Budget, Paperwork Reduction Project (0704-0188), Washington, DC 20503.

\begin{tabular}{|l|l|l}
\hline 1. AGENCY USE ONLY (Leave blank) & $\begin{array}{c}\text { 2. REPORT DATE } \\
\text { March } 2001\end{array}$ & $\begin{array}{r}\text { 3. REPORT TYPE AND DATES COVERED } \\
\text { Final Contractor Report }\end{array}$
\end{tabular}

\section{TITLE AND SUBTITLE}

Microelectromechanical Systems (MEMS) Actuators for

Antenna Reconfigurability

6. AUTHOR(S)

Rainee N. Simons, Donghoon Chun, and Linda P.B. Katehi
5. FUNDING NUMBERS

$$
\begin{aligned}
& \text { WU-755-08-0B-00 } \\
& \text { NAS3-98008 }
\end{aligned}
$$

8. PERFORMING ORGANIZATION REPORT NUMBER

E-12560

Dynacs Engineering Company, Inc.

2001 Aerospace Parkway

Brook Park, Ohio 44142

9. SPONSORING/MONITORING AGENCY NAME(S) AND ADDRESS(ES)

National Aeronautics and Space Administration

Washington, DC 20546-0001

10. SPONSORING/MONITORING AGENCY REPORT NUMBER

NASA CR-2001-210612

\section{SUPPLEMENTARY NOTES}

Prepared for the 2001 International Microwave Symposium cosponsored by the Institute of Electrical and Electronics Engineers and the Microwave Theory and Techniques Society, Phoenix, Arizona, May 20-25, 2001. Rainee N. Simons, Dynacs Engineering Company, Inc., 2001 Aerospace Parkway, Brook Park, Ohio 44142; Donghoon Chun and Linda P.B. Katehi, University of Michigan, Ann Arbor, Michigan 48109-2122. Project Manager, Erick N. Lupson, Office of Aquisition, NASA Glenn Research Center, organization code 0616, 216-433-6538.

12a. DISTRIBUTION/AVAILABILITY STATEMENT 12b. DISTRIBUTION CODE

Unclassified - Unlimited

Subject Category: 33

Distribution: Nonstandard

Available electronically at http://gltrs.grc.nasa.gov/GLTRS

This publication is available from the NASA Center for AeroSpace Information, 301-621-0390.

13. ABSTRACT (Maximum 200 words)

A novel microelectromechanical systems (MEMS) actuator for patch antenna reconfiguration is presented for the first time. A key feature is the capability of multi-band operation without greatly increasing the antenna element dimensions. Experimental results demonstrate that the center frequency can be reconfigured from few hundred $\mathrm{MHz}$ to few $\mathrm{GHz}$ away from the nominal operating frequency.

\begin{tabular}{|l|l|}
\hline 14. SUBJECT TERMS \\
Microelectromechanical systems; MEMS; Antenna; Patch \\
\begin{tabular}{c|c} 
17. SECURITY CLASSIFICATION \\
OF REPORT \\
Unclassified
\end{tabular} & $\begin{array}{c}\text { 8. SECURITY CLASSIFICATION } \\
\text { OF THIS PAGE } \\
\text { Unclassified }\end{array}$ \\
\hline
\end{tabular}

\begin{tabular}{|c|c|}
\hline & $\begin{array}{c}\text { 15. NUMBER OF PAGES } \\
10\end{array}$ \\
\hline & $\begin{array}{r}\text { 16. PRICE CODE } \\
\mathrm{AO} 2\end{array}$ \\
\hline $\begin{array}{l}\text { 19. SECURITY CLASSIFICATION } \\
\text { OF ABSTRACT } \\
\text { Unclassified }\end{array}$ & 20. LIMITATION OF ABSTRACT \\
\hline
\end{tabular}

